\title{
Caught in travertine: computed tomography reveals the youngest record of Amphicyon giganteus from the travertine deposits of Karacalar (late middle Miocene, central Anatolia, Turkey)
}

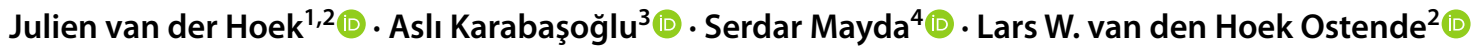

Received: 24 February 2021 / Accepted: 30 December 2021 / Published online: 19 February 2022

(c) The Author(s) 2022

\begin{abstract}
A computed tomography scan of a travertine slab from the Karacalar Silver Travertine Quarry (Afyonkarahisar Province, Turkey) revealed the presence of an encased partial cranium, partial mandible and three vertebrae. 3D reconstruction of the fossil helped identifying it as Amphicyon giganteus. As the travertine caps a section correlated to MN7/8, the specimen represents the youngest record of Amphicyon giganteus, the known range previously being limited to MN4 - MN6. This young age is in line with the more advanced morphology of the lower molars.
\end{abstract}

Keywords Afyonkarahisar - Amphicyonidae - Amphicyon giganteus $\cdot 3 \mathrm{D}$ reconstruction $\cdot$ Travertine

\section{Introduction}

The Cenozoic geological history of Anatolia has been one of much tectonic activity. Most of current-day Anatolia was shaped by the northward movement of the African and Arabian plates against the relatively stable Eurasian plate. Due to these forces and the more recent pull of the Hellenic trench, the Anatolian block has been pressed westward

Handling Editor: Irina Ruf.

Julien van der Hoek

julien.vanderhoek.5887@student.uu.se;

julienvanderhoek@gmail.com

Aslı Karabaşoğlu

aslik@aku.edu.tr

Serdar Mayda

serdar.mayda@ege.edu.tr

Lars W. van den Hoek Ostende

lars.vandenhoekostende@ naturalis.nl

1 Present Address: Department of Earth Sciences, Uppsala University, Villavägen 16, 75236 Uppsala, Sweden

2 Naturalis Biodiversity Center, P.O. Box 9517, 2300 RA Leiden, The Netherlands

3 Geological Engineering Department, Afyon Kocatepe University, 03200 Afyonkarahisar, Turkey

4 Faculty of Science, Department of Biology, Ege University, Izmir, Turkey
(McClusky et al. 2000, 2003; Reilinger and McClusky 2011). Because of this tectonic activity, Anatolia is rich in travertine deposits, as tectonic activity results in the formation of travertine from hot springs that occur along active faults (Hancock et al. 1999). Famous examples of these deposits include Kocabas, where a Homo erectus was found in travertine (Kappelman et al. 2008), and Pamukkale, which is a UNESCO-World Heritage Site and tourist attraction.

Travertine provides a suitable fossilization environment, as animal and plant remains can be quickly sealed off. As it consists primarily of calcium carbonate, it is an excellent material for the preservation of bones and teeth. Moreover, the fossil is protected from the acidic properties of rain that might cause corrosion or dissolution, as the first stages of decalcification are primarily focused on the travertine instead of on the fossil itself (Walker 2005). The enclosed fossils can be used to give an age estimate for the travertine (e.g., Erten et al. 2005). Direct dating of the rock is difficult, as the carbonate minerals that make up travertine are often formed at different times, rates, and in different locations (Pentecost 2005). Moreover, radiometric dating with ${ }^{14} \mathrm{C}$ or ${ }^{234} \mathrm{U} /{ }^{230} \mathrm{Th}$, Electron Spin Resonance, and thermoluminescence dating all have age limits that make them unsuited for dating anything beyond the Pleistocene (Dreimanis 1978; Grün 2005; Pentecost, 2005). Of course, if the travertine is part of a larger section, radiometric dating of other layers and palaeomagnetostratigraphy can be used to infer a time of deposition. In the case of the Homo erectus from 
Kocabaş, this proved especially useful, as the Villafranchian fauna from the site per se could not provide as precise a date (Lebatard et al. 2014). However, usually, the enclosed fossils are the only way to date a travertine deposit.

Unfortunately, studying fossils from travertine deposits provides a major logistic challenge. Encased in a hard matrix, it is almost impossible to study the fossils directly. Computed tomography scans can provide a solution. In this paper, we describe a carnivoran skull and mandible preserved in a travertine slab from the Karacalar Silver Travertine Quarry, in the province of Afyonkarahisar around $200 \mathrm{~km}$ southwest of Ankara. On the basis of X-ray images, it was hypothesized that the fossil represented a large-sized amphicyonid, although at that stage, a primitive ursid could not be excluded. Therefore, the fossil was reconstructed using computed tomography to provide an accurate identification and description. Apart from our interest in the fossil itself (carnivoran skulls are relatively rare in the fossil record), we hoped that the fossil would allow us to assign an age to the travertine itself. The quarry is situated in the upper part of the Gebeceler Formation. The lower part of that formation yielded a mammalian fauna with Anchitherium sp., Hispanotherium grimmi, Caementodon cf. caucasicum, Micromeryx flourensianus, Triceromeryx sp., Hispanomeryx sp., Giraffokeryx sp. nov., and Sinapospalax cf. berdikensis, allowing a correlation to MN7/8 (Saraç 2003; Mayda et al. 2013). Thus, the maximum age for the Karacalar fossil is set at the end of the middle Miocene.

\section{Geological setting}

The oldest geologic units in the study area are the Paleozoic crystalline metamorphic rocks (Metin et al. 1987). These rocks are mostly composed of marble, calcschist, albite-chlorite-muscovite-quartz schist and meta-conglomerate levels. In addition to these, porphyroid rocks in metamorphics cover large areas in the southwest of Afyon. The upper contact of the Afyon metamorphites is discordantly overlain by the Mesozoic and Miocene units. The Mesozoic units in the area are defined as the Bolkardağ 1 unit (Özgül 1976). These formations are called Tozlutepe (Middle - Late Triassic), Koçakkaletepe (Jurassic - Cretaceous) and Kaledere (Late Cretaceous) (Alan et al. 2007). Neogene units consist of lacustrine environment products, with the Miocene aged Gebeceler Formation and Köroğlu Volcanics consisting of equally aged volcanic rocks transitive in lateral and vertical direction (Seydiler Pyroclastic Member, Kocatepe Lava Member and Karakaya basalt member). These are lahar, recoil deposits, ignimbrite, block-ash flows and trachytic lavas which are products of volcanism.

The Gebeceler Formation exposed on most areas surrounding the Karacalar Village consists of pebble stone, pebbly sandstone, tuff- tuffite clayey limestone at the base, thin-medium bedded marls and transitional lacustrine limestones. The thickness of the unit reaches $345 \mathrm{~m}$ (Metin et al. 1987). In previous studies, mammal fossils were mentioned from the unit, dating it to the middle Miocene (Saraç 2003). In addition, $11.6 \pm 0.25 \mathrm{my} \mathrm{K} / \mathrm{Ar}$ age was taken from tuffite levels in volcanoclastics (Besang et al. 1977). There are many travertine quarries in the region, where the lacustrine limestones are mined as natural stones (travertine). In these lacustrine limestones, vertebrate fossil remains, plant fossils, fossil reeds and algae have been identified. These travertine deposits were formed as a result of many inactive faults.

\section{Material and methods}

\section{Material}

The fossil was found in 2018 during quarrying at the Karacalar Silver Travertine Quarry at $38^{\circ} 58^{\prime} 44.78^{\prime \prime} \mathrm{N}$, $31^{\circ} 15^{\prime} 58.23^{\prime \prime} \mathrm{E}$ (Fig. 1). The travertine was cut by the quarrying operations into a slab that is about $43 \mathrm{~cm}$ long, $43 \mathrm{~cm}$ wide and $4 \mathrm{~cm}$ thick. A mandible, partial cranium and a few vertebrae can be distinguished in the slab (Fig. 2). The studied material is stored in the Afyon Kocatepe University Geology Department under the temporary inventory number Afyon-1. It will later be moved to be stored under a permanent inventory number in the same department.

\section{Computed tomography scan}

The travertine slab was placed into a computed tomography scanner in the Medical Research centre of Afyonkarahisar. 899 pictures were taken of cross sections in three dimensions. The machine used for the CT-scan was the Aquilion Prime with an exposure time of $12 \mathrm{~h}$, $20 \mathrm{~min}$ and $57 \mathrm{~s}$ at $120 \mathrm{kV}$. The resulting voxel size was $0.876021 \times 1 \times 0.876021$.

\section{D reconstruction}

Avizo 2019.4 was used to segment the fossil and to create a $3 \mathrm{D}$ reconstruction by stacking the segmented materials three-dimensionally (Fig. 3). The mandible, cranium and teeth were each segmented using the brush tool to colour each different material by hand. After segmentation, the 3D reconstruction was smoothed by first using Remove islands on all connected regions smaller than 15 voxels on all slices. Then, Smooth labels was used on size three on the 3D-Volume. The use of Remove islands, Smooth labels and their tool settings were taken from the tutorial "3.5 Segmentation of 3D images" from the user's guide for Avizo software (ThermoFisher Scientific 2018). 

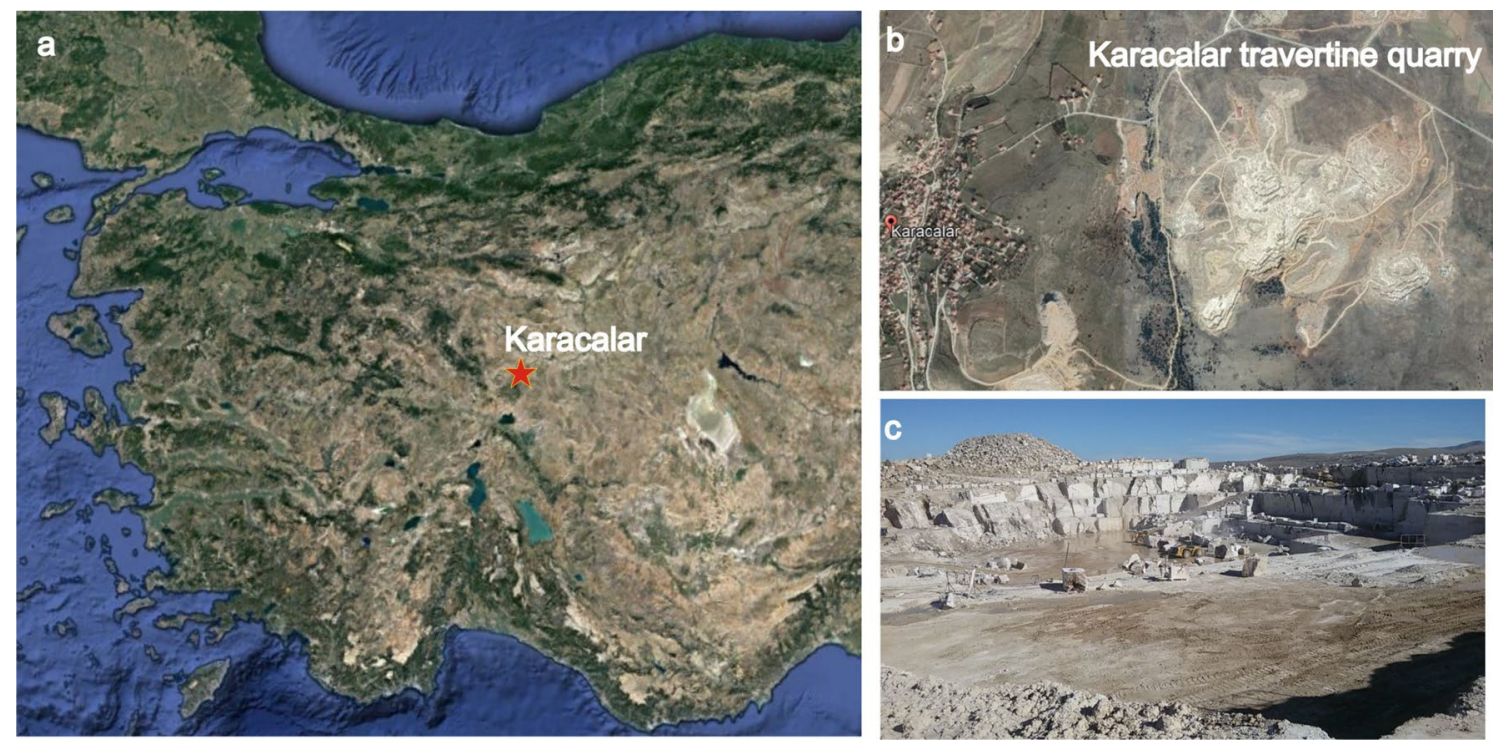

Fig. 1 a, b Location map (enlarged) of the study area. The locality Karacalar is indicated by an asterisk, Sample coordinate: $38^{\circ} 58^{\prime} 44.78^{\prime \prime} \mathrm{N}$, $31^{\circ} 15^{\prime} 58.23^{\prime \prime}$ E. c Close-up photograph of the Karacalar travertine field

Fig. 2 Karacalar travertine slab in situ

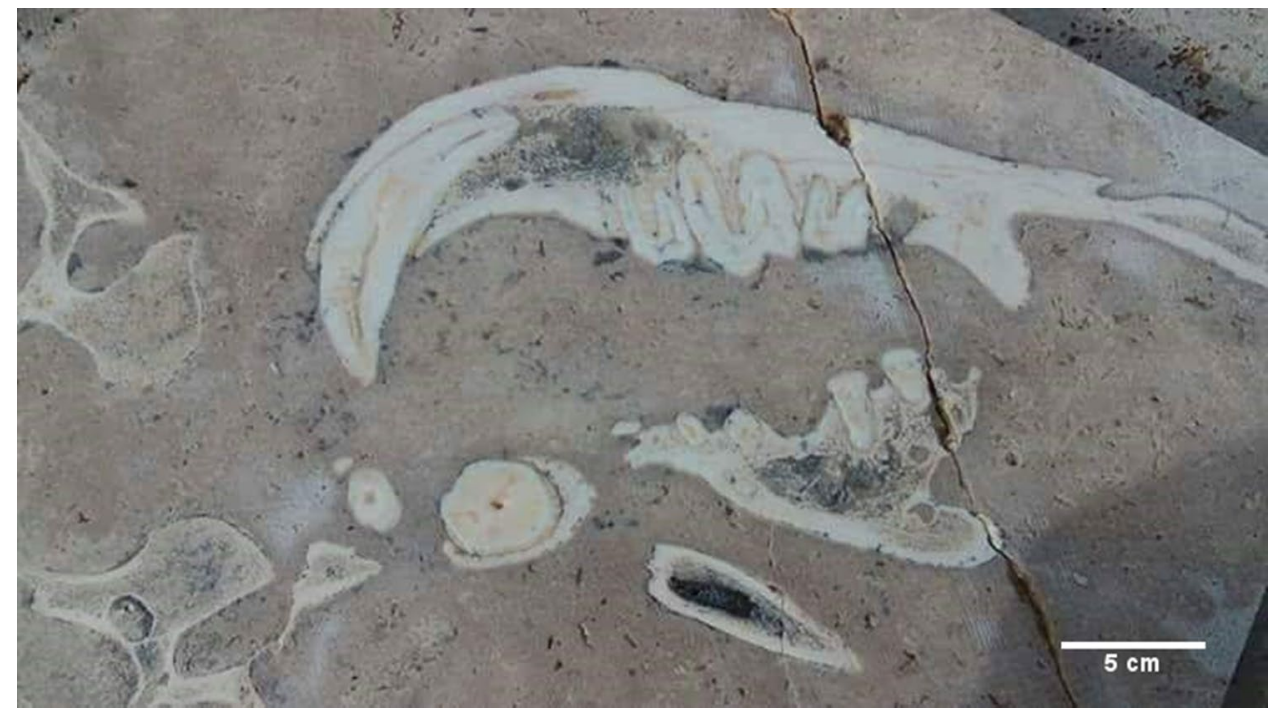

\section{Measurements}

The dental nomenclature used follows Schmidt-Kittler (1976). Measurements were taken according to the protocol developed by Peigné and Heizmann (2003). The measurements were taken using the measurement tool in Avizo. Measurements were taken with an accuracy of $0.1 \mathrm{~mm}$ (Table 1).

\section{Systematic palaeontology}

Order Carnivora Bowdich, 1821
Family Amphicyonidae Haeckel, 1866

Subfamily Amphicyoninae Haeckel, 1866

Genus Amphicyon Lartet, 1836

Type Species. Amphicyon major de Blainville, 1841

Amphicyon giganteus (Schinz, 1825)

See Ginsburg and Antunes (1968) for a synonymy list before 1968. 
Fig. 3 3D reconstruction of the Afyon-1 specimen of Amphicyon giganteus in labial view. Scale bar of $100 \mathrm{~mm}$

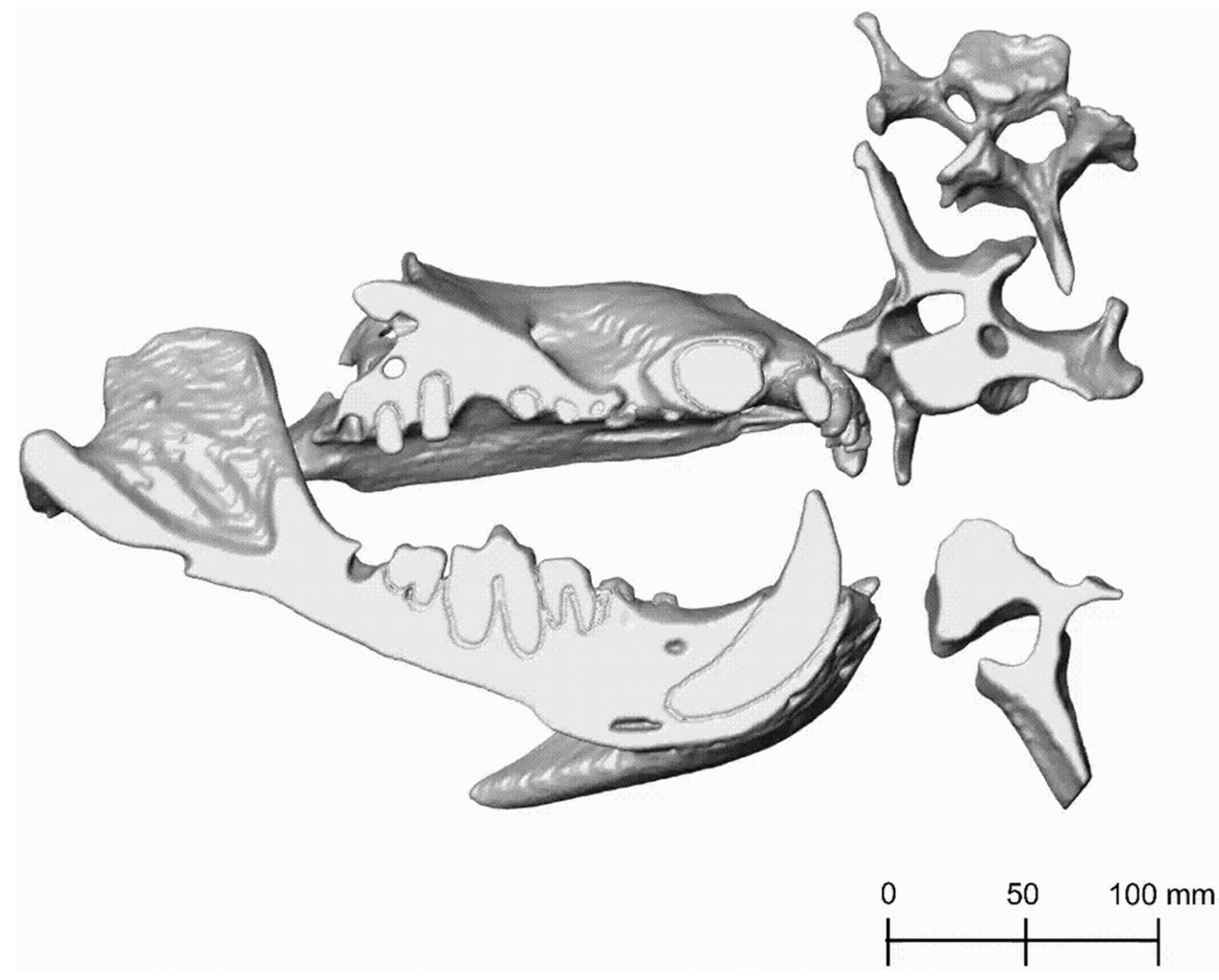

\begin{tabular}{|c|c|c|}
\hline & 1968 & $\begin{array}{l}\text { Amphicyon giganteus Ginsburg and Antunes } \\
\text { (1977), pp. 9-12, 14-19, 24, figs. 1-24, 28, } \\
29,31\end{array}$ \\
\hline$?$ & 1977 & $\begin{array}{l}\text { Amphicyon giganteus carnutense Ginsburg and } \\
\text { Antunes (1977), p. } 341\end{array}$ \\
\hline$?$ & 1984 & $\begin{array}{l}\text { Amphicyon giganteus de Beaumont (1984), p. 81, } \\
\text { pl. 1, figs. 1-5 }\end{array}$ \\
\hline$?$ & 1989 & $\begin{array}{l}\text { Amphicyon giganteus carnutense Ginsburg } \\
(1989,2000), \text { p. 103, figs. } 1-4\end{array}$ \\
\hline \multirow[t]{8}{*}{$?$} & 1996 & Amphicyon giganteus Viranta, p. 16, fig. 3 \\
\hline & 1998 & $\begin{array}{l}\text { Amphicyon giganteus Morales, Pickford, Soria } \\
\text { and Fraile (1998), p. 32, fig. } 7\end{array}$ \\
\hline & 2000 & $\begin{array}{l}\text { Amphicyon giganteus Ginsburg }(1989,2000) \text {, } \\
\text { p. } 36\end{array}$ \\
\hline & 2003 & $\begin{array}{l}\text { Amphicyon giganteus Morales, Pickford, } \\
\text { Fraile, Salesa and Soria (2003), p. 191, pl. 4, } \\
\text { figs. 4-6 }\end{array}$ \\
\hline & 2006 & $\begin{array}{l}\text { Amphicyon giganteus Peigné, Salesa, Antón and } \\
\text { Morales (2006b), p. 365, pl. 2, figs. 1-15 }\end{array}$ \\
\hline & 2018 & $\begin{array}{l}\text { Amphicyon giganteus Bastl, Nagel, Morlo and } \\
\text { Göhlich (2018), p. 4, fig. } 2\end{array}$ \\
\hline & 2019 & $\begin{array}{l}\text { Amphicyon giganteus Morlo, Miller, Bastl, } \\
\text { Abdelgawad, Hamdan, El-Barkooky and Nagel } \\
\text { (2019a), p. 739, fig. } 4\end{array}$ \\
\hline & 2020 & $\begin{array}{l}\text { Megamphicyon giganteus Siliceo, Morales, } \\
\text { Antón and Salesa (2020), pp. 225, 227-232, } \\
\text { figs. 1-7 }\end{array}$ \\
\hline
\end{tabular}

Holotype: Left M1 from Avaray (Loir-et-Cher), stored at the Museé d'Orléans. Figured by Cuvier (1824, pl. 193, fig. 20); Mayet (1908, p. 83, fig. 24, p. 211, fig. 68, pl. 8, fig. 7); Kuss (1965, p. 68, fig. 42).

Range: $\mathrm{MN} 4-\mathrm{MN} 7 / 8$.

Occurrence: Anatolia, Europe, Egypt, Namibia.

Material: Encased partial cranium and mandible, partially cut off on the side of the slab, Afyon-1.

\section{Description}

\section{Lower dentition}

On the right mandible, one procumbent i3 was preserved, which is longer than it is wide (Fig. 4). The mesial side of i3 is concave; the distal side is convex. The root of i3 is convex on the mesial side, while on the distal side of the crown, the root starts out convex tapering to the right, but the lower end is flattened. There is a clear gap between i3 and $\mathrm{c}$. The canine is robust, recurved and has a ridge on the lingual side, which extends from the base to the tip of the crown, due to angular cutting of the slab. Diastemata are of variable length. While a large diastema separates the canine from the $\mathrm{p} 2$, diastemata between $\mathrm{p} 2-4$ are smaller. The $\mathrm{p} 1$ 


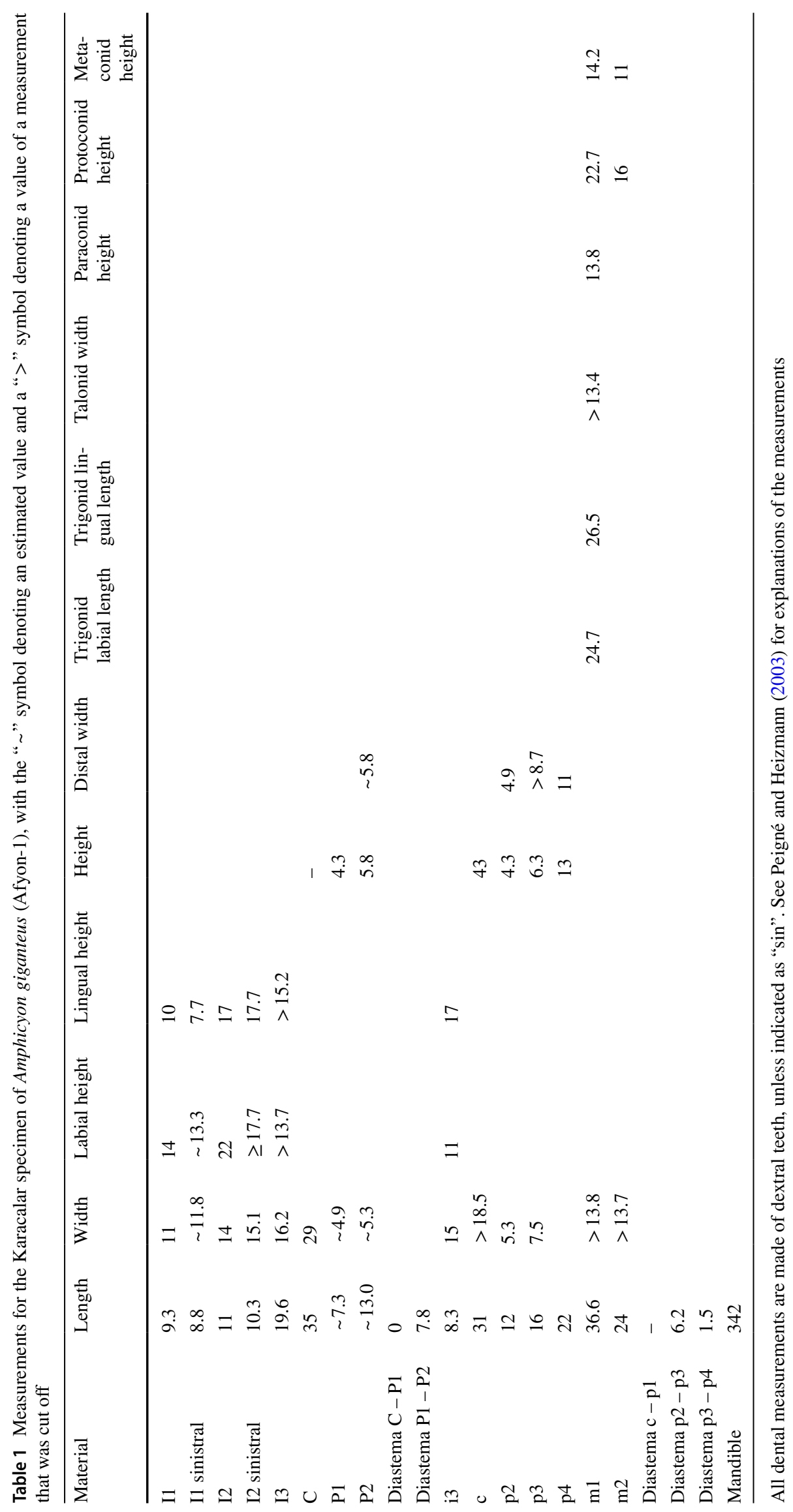


and its alveolus are absent (Fig. 5). The mesial roots of $\mathrm{p} 2$ and $\mathrm{p} 3$ are thicker than their distal roots. The $\mathrm{p} 2$ is small, lingually placed and double rooted. It is oval in occlusal view and has one cusp (Fig. 6). From the p3 onwards, the teeth are partially cut off at a diagonal angle on the labial side by the surface of the slab. This affected mostly the crowns of $\mathrm{p} 3, \mathrm{p} 4, \mathrm{~m} 1$ and $\mathrm{m} 2$, although the roots are more completely preserved. The $\mathrm{p} 3$ is much more robust than the $\mathrm{p} 2$. It is double rooted and has an accessory tubercle distally from the main cusp. The $\mathrm{p} 4$ is much more robust than the $\mathrm{p} 3$, the size difference has a similar ratio as the difference between $\mathrm{p} 2$ and $\mathrm{p} 3$. The $\mathrm{p} 4$ is double rooted and has a more robust distal accessory tubercule than the $\mathrm{p} 3$. The $\mathrm{m} 1$ is a robust tooth, which is cut off on the labial side. It is labiolingually flattened. It has a strong, high paraconid. The protoconid is high with a metaconid present as a small cusplet in the flank and near the base of the protoconid. The broad talonid has a large labially placed hypoconid and a reduced entoconid. The talonid basin is widest behind the metaconid and protoconid. The mesial root is thinner than the distal root, with a ratio of about 3:5. The $\mathrm{m} 2$ is about $66 \%$ smaller than the $\mathrm{m} 1$. It appears to be sub-rectangular in occlusal view; the labial side is cut off. The $\mathrm{m} 2$ has a reduced paraconid; metaconid and protoconid are of about equal size, forming
Fig. 4 i3, c and alveoli of the Afyon-1 specimen of Amphicyon giganteus in lingual view, cranium and vertebrae excluded from the reconstruction. Scale bar of $50 \mathrm{~mm}$
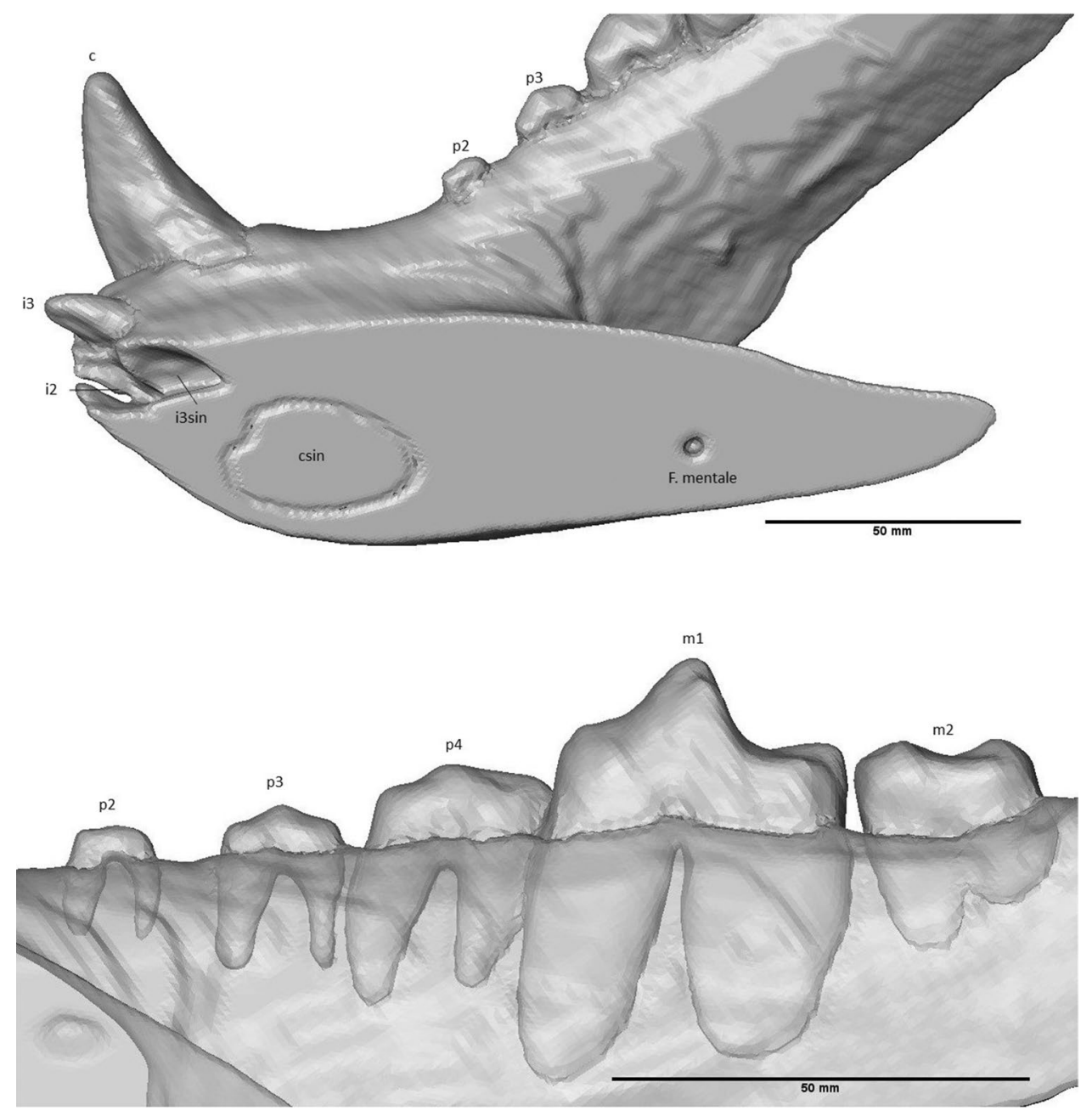

Fig. $5 \mathrm{p} 2-\mathrm{m} 2$ of the Afyon-1 specimen of Amphicyon giganteus in lingual view, roots were made visible by setting transparency to 0.5 . Scale bar of $50 \mathrm{~mm}$

Fig. 6 p $2-\mathrm{m} 2$ of the Afyon-1 specimen of Amphicyon gigan teus in occlusal view, cranium excluded from the reconstruction. Scale bar of $50 \mathrm{~mm}$

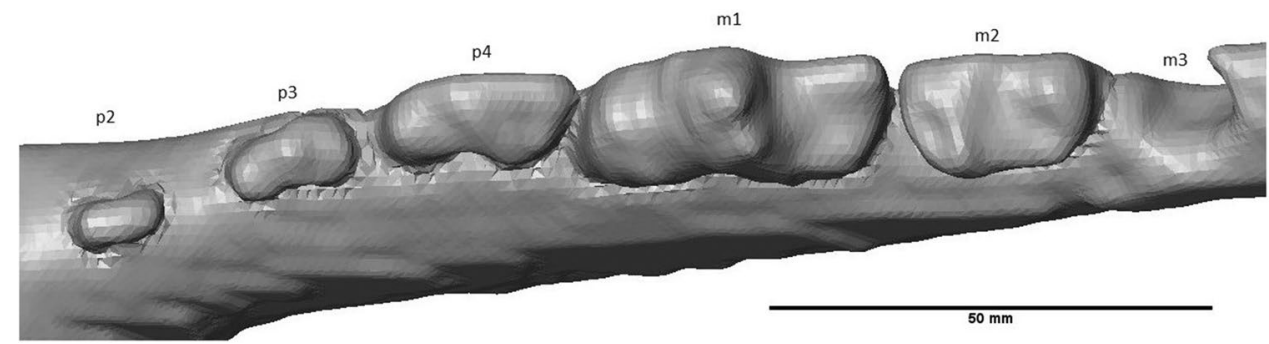


a ridge across the trigonid. The talonid is dominated here by the hypoconid as well. The entoconid curves slightly along the posterolingual corner of the talonid. The roots have a similar relative thickness as in the $\mathrm{m} 1$. Behind the $\mathrm{m} 2$, the alveolus of a single-rooted $\mathrm{m} 3$ is preserved.

\section{Mandible}

Two alveoli belonging to the roots of incisors are situated mesially to the dextral i3. The first alveolus in order is in line with the tooth row and is slightly smaller than the alveolus of i3, which suggests that it is an i2. The second alveolus is placed more towards the sinistral side than i2 and rotated at a similar angle as i3. Due to this placement and angle, it is interpreted as a sinistral i3. A root of a canine is visible on the sinistral side of the fossil, but it does not match the angle of the dextral canine and seems to be situated less ventrally in the mandible. It is interpreted here as the root of the sinistral canine.

A porous structure can be seen throughout the mandible mesial to the canine and i3 (Fig. 7). The presence of this structure suggests some crushing occurred in this location during fossilization. The anterior foramen mentale is preserved both on the right and the left side, below the i3 and the alveolus of that element, respectively. It aligns via a long internal canal with mental foramina that can be seen as an oval-shaped opening on the dextral side of the fossil underneath the proximal root of the $\mathrm{p} 2$ and distal root of the p3 and as a smaller opening on the sinistral side underneath the p3 (Fig. 8). On the labial side, the mesial border of the ascending ramus has been preserved. The condyle is cut off on both the lingual and labial side. It is situated above the tooth row.

\section{Upper dentition}

Only part of the sinistral side of the specimen was preserved due to the angle in which the travertine slab was cut. In this way, the sinistral I1 and I 2 are preserved next to the anterior part of the dextral dentition (Fig. 9). The incisors become progressively larger in size and are single rooted. They are notably robust. The dextral I1 is convex on the mesial side, but flattened on both the distal side and along the labiolingual axis. This morphology differs notably from the sinistral I1, which appears damaged due to the erosion of the front of the fossil also seen in the displaced lower canine. It is similarly sized, but has an elongated and narrow apex on the labiolingual axis. Its root is exposed. The dextral I 2 is larger than I1 and curves towards I3. It is narrow and elongated, convex mesially and concave distally. The apex is a rounded edge. The sinistral I 2 is cut off by the travertine slab. On its lingual face, the tooth curves mesially. Its apex is rounded. I3 is a caniniform, robust tooth. The tooth is cut off on the labial side. The root of the tooth is curved. Only the root and the base of the crown of the upper canine have been preserved; based on their sizes, the $\mathrm{C}$ can be interpreted as a robust tooth. The root narrows dorsoventrally in a lingual direction from the base of the crown to the tip of the root. P1 is a small, unicuspid and single-rooted tooth, laying in close proximity to the canine (Fig. 10). P2 is double rooted and unicuspid, oval in shape from an occlusal view. P3, P4, M1 and $\mathrm{M} 2$ are cut off at such an angle that mostly the roots are preserved. Only a small fragment of the crown is preserved in these teeth. P3 has partial preservation of two roots, but P4 to M2 only have one root with a small fragment of the crown preserved. A gap is present between the root of P4 and the root of M1, as a result of the two labial roots of the
Fig. 7 Anterior part of the crushed mandible of the Afyon-1 specimen of Amphicyon giganteus. Scale bar of $50 \mathrm{~mm}$

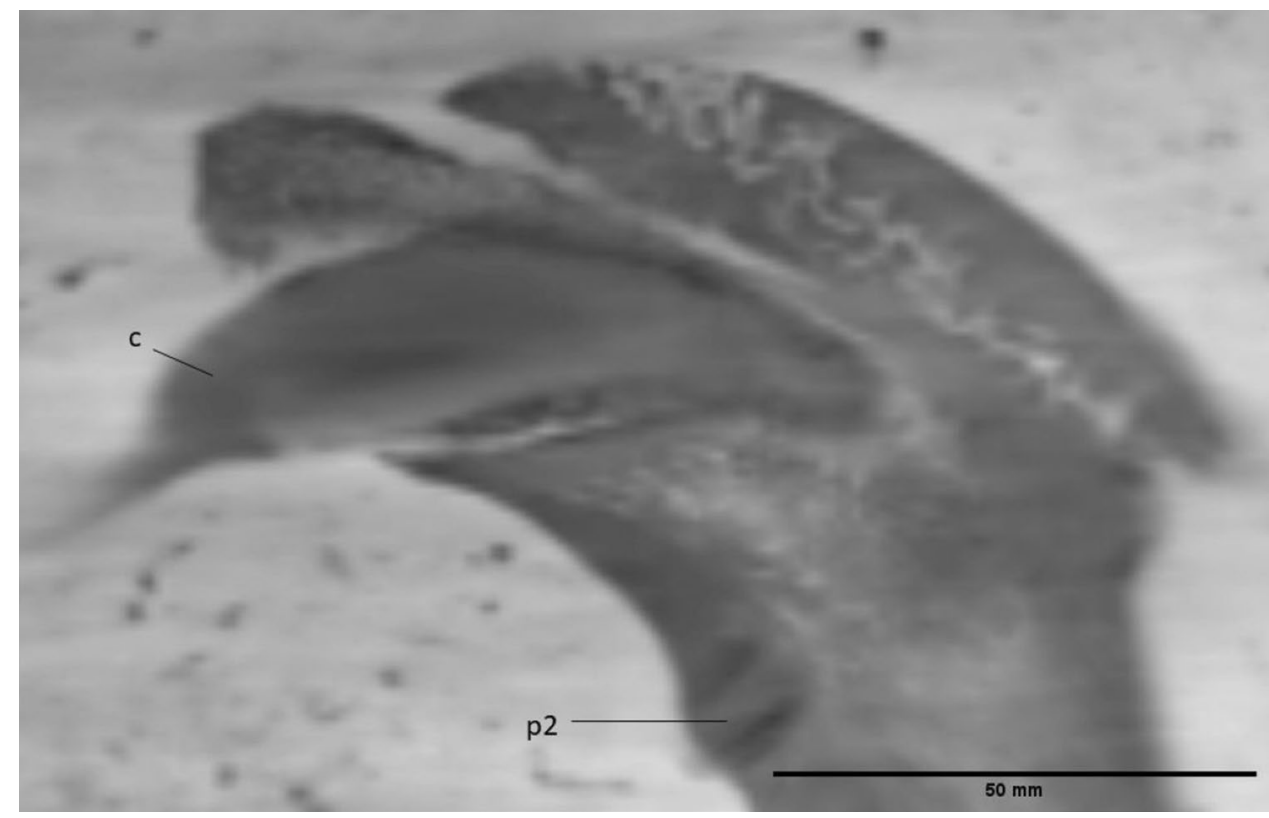




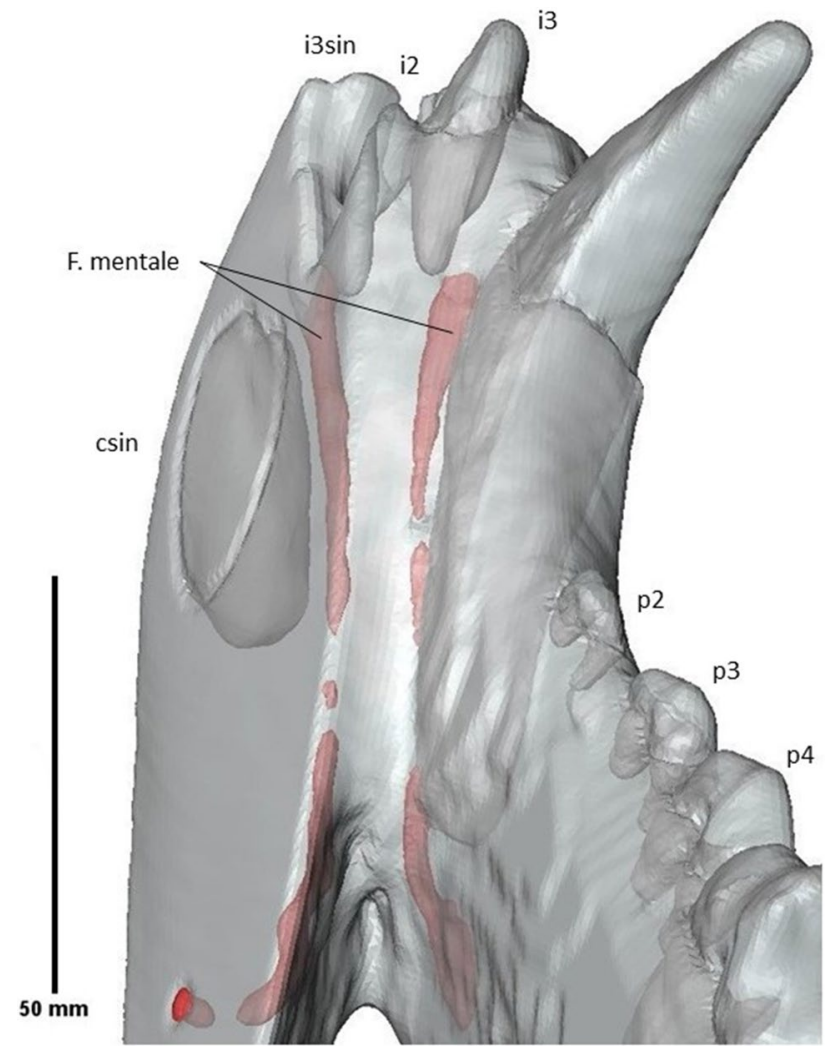

Fig. 8 Long, fragmented canals of the mental foramina (in red) of the Afyon-1 specimen of Amphicyon giganteus. The canals were made visible by first segmenting the tunnels, and then setting transparency to 0.5 , vertebrae and cranium excluded, lingual view. Scale bar of $50 \mathrm{~mm}$

P4 having been cut off. An alveolus can be seen distally to the last root of the maxilla, which is interpreted as the alveolus of the root of M3.

\section{Cranium}

Part of the bony palate can be distinguished, with a palatine fissure. The most anterior part of the zygomatic bone is preserved. The most posterior part of the skull preserved is part of the pterygoid bone. The back of the cranium seems to be damaged. In anterior view, the nasal aperture and the infraorbital foramen can be distinguished. Posteriorly, the infraorbital foramen continues into a narrow infraorbital canal that widens towards the end. The nasal cavity is large and deep and can be seen in lingual and anterior views.

\section{Comparison}

Both the premolars and the metaconid of $\mathrm{m} 1$ are clearly in reduction, which would suggest an adaptation to hypercarnivory similar to genera such as Tomocyon or Agnotherium

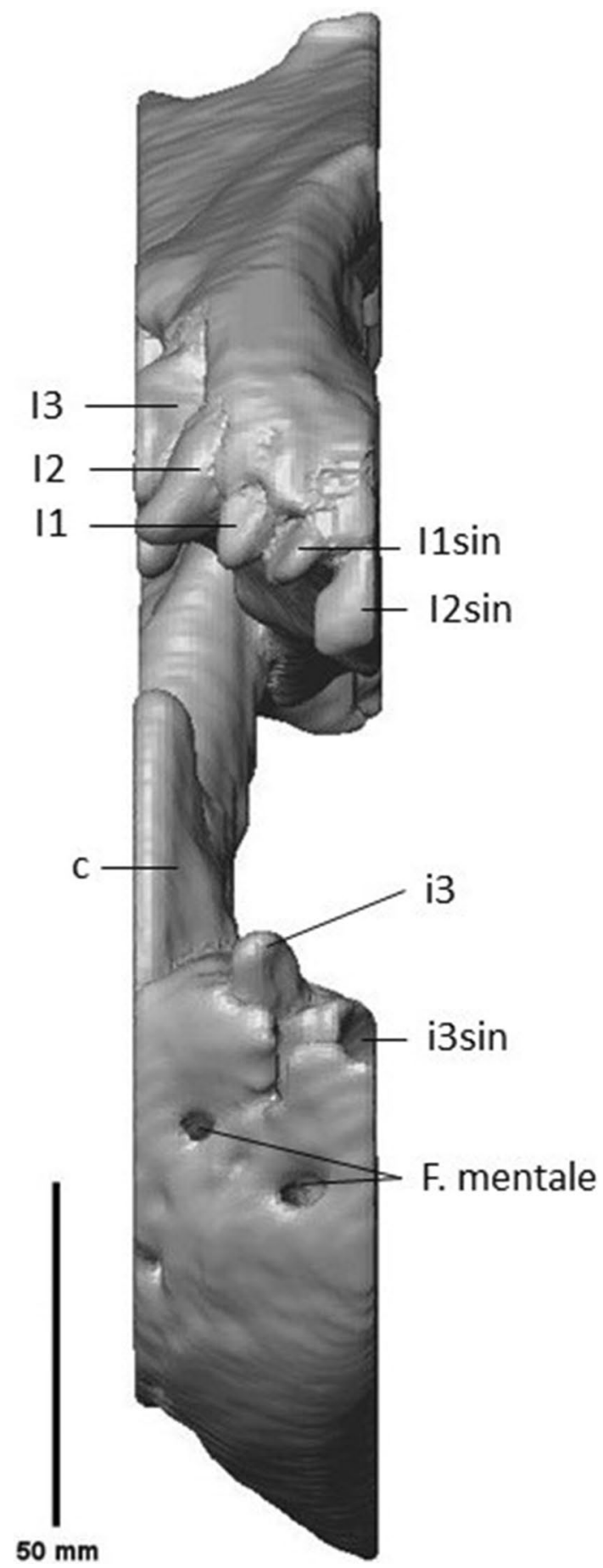

Fig. 9 Partial cranium and mandible of the Afyon-1 specimen of Amphicyon giganteus in anterior view, vertebrae excluded from the reconstruction. Scale bar of $50 \mathrm{~mm}$

(Morlo et al. 2019a, b; Viret 1929). Unlike Agnotherium, however, the metaconids on the $\mathrm{m} 1$ and the premolars are not as extremely reduced (Morlo et al. 2019a, b). Tomocyon also does not possess a metaconid on the $\mathrm{m} 1$. It has a taller 


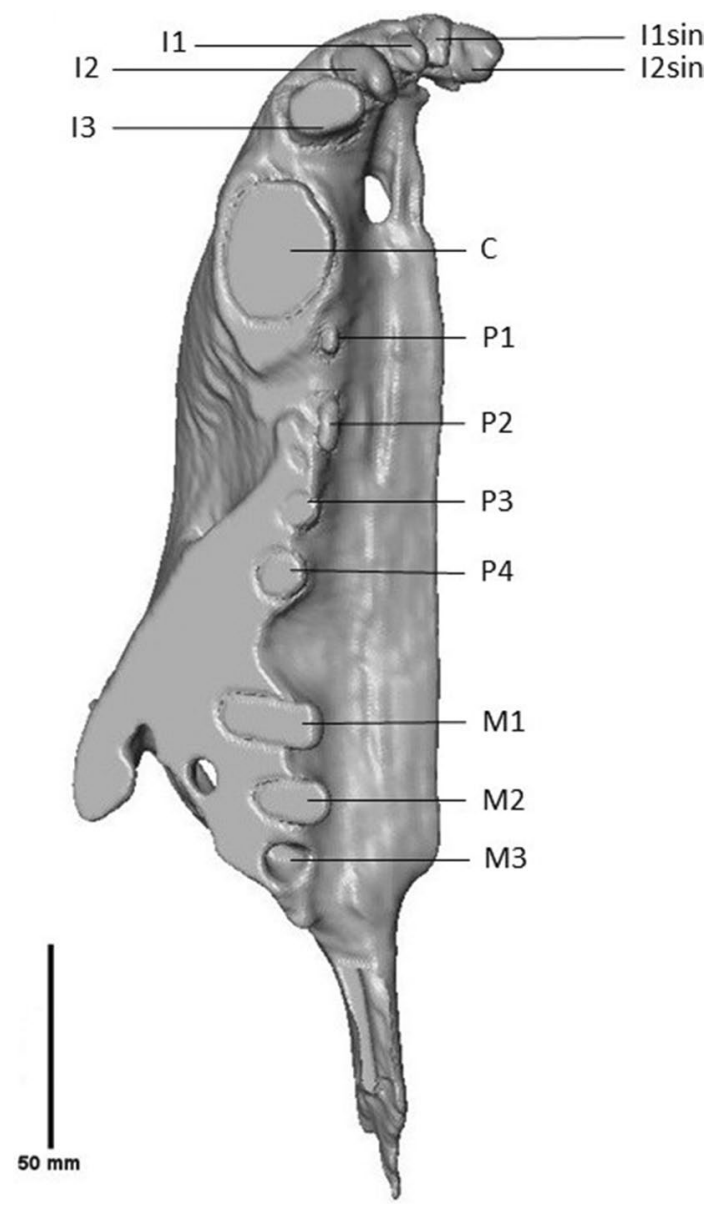

Fig. 10 Partial cranium of the Afyon-1 specimen of Amphicyon giganteus in ventral view, mandible and vertebrae excluded from the reconstruction. Scale bar of $50 \mathrm{~mm}$

talonid on the $\mathrm{m} 1$ than Afyon-1. The $\mathrm{p} 4$ of Tomocyon is much taller than the p4 of Afyon-1 (Viret 1929).

Based on the robust dental elements, the diastemata between the premolars and the presence of an entoconid on the $\mathrm{m} 1$ (Viranta 1996), the Karacalar specimen can safely be attributed to the genus Amphicyon. Within the genus, it shows the greatest similarity with $A$. major and A. giganteus, which are morphologically similar, with $A$. giganteus generally being larger (Viranta 1996).

No upper dentition behind the $\mathrm{P} 2$ was preserved. These teeth, especially the upper carnassial and molars, are often used in identifying Amphicyonidae and separating Amphicyon giganteus from A. major (Gürbüz 1974; Peigné et al. 2006b; Jiangzuo et al. 2019). Another characteristic often used in separating the taxa is size, but both A. giganteus and $A$. major display significant variation in size, which can largely be explained by sexual dimorphism, as males are larger than females in both species (Viranta 1996). These size variations were estimated to be up to $20 \%$ for $A$. major and slightly over 30\% for A. giganteus (Ginsburg and Antunes 1968).

Whereas absolute size needs to be used with caution, the relative size of the anterior dentition differs markedly between the two species, the upper incisors, lower premolars and canines being relatively smaller in Amphicyon major. This size difference in anterior dentition is clearly visible when comparing data from Bergounioux and Crouzel (1973) and Peigné (2012). In Fig. 11, we plotted the lengths of the elements of the Karacalar specimen against that of A. major from its type locality Sansan, setting the value of the latter to 1 . The measurements used for this plot are presented in Appendix I1 and II Appendix 2 for the upper and lower dentition, respectively.

The Karacalar specimen fits the descriptions of Amphicyon giganteus by Ginsburg and Antunes (1968) in their overview of the species based on material from France, Germany, Austria, Switzerland and Portugal. When looking at the $\mathrm{m} 1$ of the Karacalar specimen, the talonid basin is not at its largest behind the posterior crest of the hypoconid, which would be a characteristic of $A$. major. The tooth is also more robust, with stronger cingulids. When looking at the $\mathrm{m} 2$, the tooth resembles the occlusal view of the $\mathrm{m} 2$ from Captieux, but no clear morphological differences separate the $\mathrm{m} 2$ from that of A. major.

The dentition of Amphicyon giganteus was described by Viranta (1996), based on material from France and Spain, with additional data from Ginsburg and Antunes (1968). Viranta mentioned a double-rooted $\mathrm{m} 3$ for the material from Neuville-aux-Bois (MN3). This material was later redefined as belonging to A. laugnacensis (Ginsburg 1999). In younger material from Arrisdrift, Moghra and Arroyo del Val, the last lower molar is described as single rooted (Morales et al. 1998, 2003; Peigné et al. 2006b; Morlo et al. 2019a, b). The $\mathrm{m} 3$ from the Karacalar specimen is single rooted as well. Thus, the $\mathrm{m} 3$ of A. giganteus is single rooted. Viranta (1996) also indicated the presence of a cingulid around $\mathrm{m} 1$. A cingulid is identified in material from Moghra (Morlo et al. 2019a, b), but not in other material (e.g., Morales et al. 2003; Bastl et al. 2018; Siliceo et al. 2020), and is also absent in the Karacalar specimen. The other characteristics can be identified in both the Karacalar specimen and most specimens identified as A. giganteus.

PQAD 1520, a mandible from Arrisdrift, Namibia, was placed in Amphicyon giganteus as opposed to A. major based on its larger premolars, lack of diastemata between the premolars and its overall large size (Morales et al. 1998, 2003). The Amphicyon giganteus material from Moghra, Egypt shows great similarity to the material of Arrisdrift (Morales et al. 1998, 2003; Morlo et al. 2019a, b). CUWM 53 shares the double-rooted p2, lack of diastemata, low metaconid and well-developed hypoconid on $\mathrm{m} 1$, an $\mathrm{m} 2$ with a paraconid and the presence of a single-rooted $\mathrm{m} 3$ with PQAD 1520 
2.5

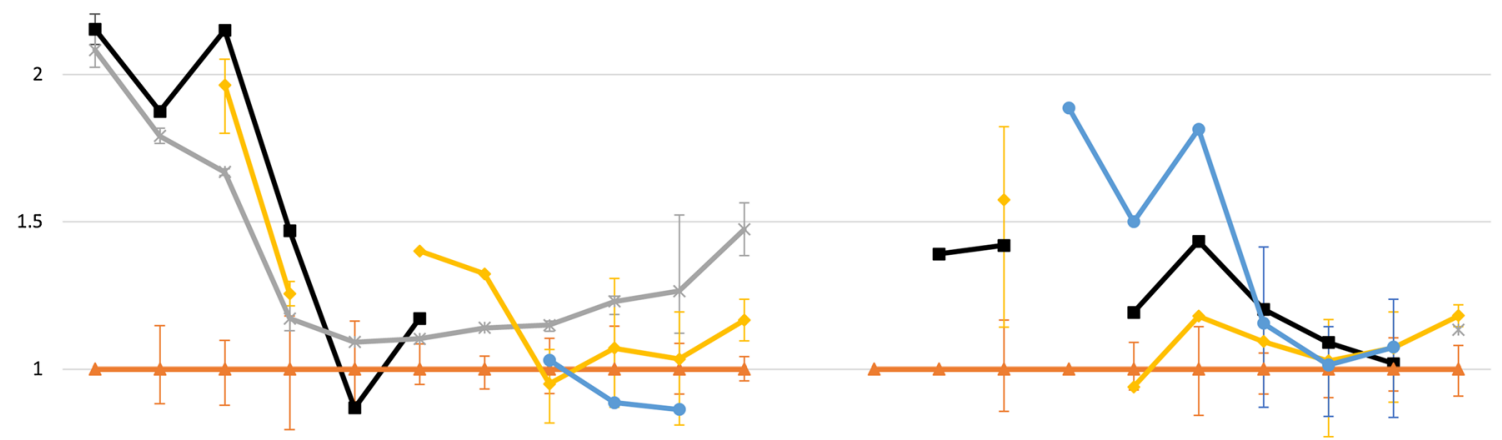

0.5

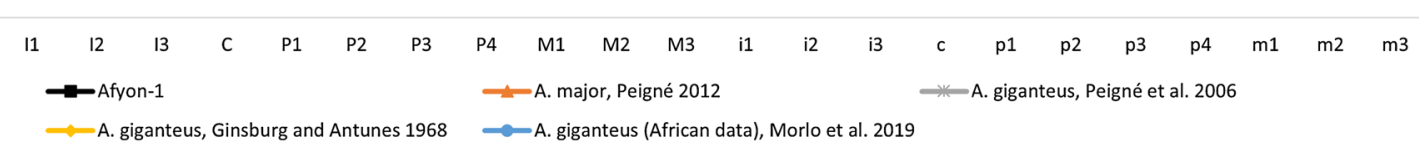

Fig. 11 Afyon-1 dental length compared to Amphicyon major and A. giganteus, scaled relative to the material of A. major from Sansan. Error bars represent the size ranges of the teeth. The data were

taken from Ginsburg and Antunes (1968), Peigné (2012), Morlo et al. (2019a, b), Peigné et al. (2006a, b)

(Morlo et al. 2019a, b). As such, CUWM 53 shows similar affinities with the Karacalar specimen as PQAD 1520. The larger premolars in the African material can also be seen in the Karacalar specimen and fits in the range of $A$. giganteus (Viranta 1996). In contrast to the Arrisdrift and Moghra specimens, diastemata are present between the premolars of the Karacalar specimen, but they are smaller than those recorded for the A. major material from Sansan (Bergounioux and Crouzel 1973). This difference in diastema size is also used in some cases as a characteristic separating $A$. giganteus from A. major (e.g., Morales et al. 1998, 2003; Morlo et al. 2019a, b).

Amphicyon giganteus material from La Barranca (Arroyo del Val area, MN6) has incisors, canines and premolars that resemble the Karacalar specimen. Peigné et al. (2006b) stated that these teeth are not indicative of A. giganteus in themselves and based their identification on the morphology of the P4. However, the La Barranca anterior dentition is close in length to the Karacalar specimen and, more importantly, shows a similar relative size to the typical $A$. major (Fig. 11). According to Peigné et al. (2008), Amphicyon major and A. giganteus also have different ratios of the length of the $\mathrm{p} 4$ to the length of the $\mathrm{m} 1$. For $A$. major, this range is $0.48-0.54$, while it is $0.51-0.60$ for $A$. giganteus (Peigné et al. 2008). The $\mathrm{p} 4 / \mathrm{m} 1$ ratio of the Karacalar specimen is 0.59 , fitting well into the range of A. giganteus.

Material from Gračanica (Bosnia and Herzegovina, MN5) includes a dextral p4 - m2 belonging to Amphicyon

giganteus, with a fragmentary $\mathrm{p} 4$ (Bastl et al. 2018). The molars have a similar length as the Karacalar specimen. Other commonalities are the distal accessory cusp in $\mathrm{p} 4$, the robustness of the crown and roots of $\mathrm{m} 1$, a metaconid that is close to the protoconid in $\mathrm{m} 1$ and the occlusal outline of $\mathrm{m} 2$.

Recently, material of Amphicyon giganteus was described from the MN6 locality of Carpetana, Spain (Siliceo et al. 2020). The material agrees with the Karacalar specimen for the morphology of the premolars are the diastemata between p2-p4, the p3 and p4 with distal accessory cuspids and large p4. The morphology of the molars is similar as well, with a labiolingually flattened $\mathrm{m} 1$ with a short paraconid and the metaconid close to the protoconid, a large hypoconid on $\mathrm{m} 1$ and $\mathrm{m} 2$ and reduced paraconid on $\mathrm{m} 2$.

Given the similarity of the Karacalar specimen to material previously described as Amphicyon giganteus, there can be little doubt that it belongs to that taxon. The only notable difference is the absence of diastemata in the African material, but, as we have not seen those specimens, that falls outside the scope of this paper. The material from Karacalar is identified as A. giganteus based on its size, double-rooted $\mathrm{p} 2$, robust incisors and canines, $\mathrm{m} 1$ with a narrow talonid basin and metaconid in close proximity to the protoconid, large premolars and small diastemata between them.

Based on previously published material, a number of evolutionary trends can be observed within the species for a number of these structures in the lower dentition (Ginsburg and Antunes 1968). Plesiomorphic characteristics 
include a more hollowed-out talonid in the $\mathrm{m} 1$ and an $\mathrm{m} 2$ that is reduced distally and has a strong paraconid. More derived specimens have an $\mathrm{m} 1$ with a talonid with a less hollowed-out interior that shrinks gradually and a more rectangular $\mathrm{m} 2$, with a barely indicated paraconid (Ginsburg and Antunes 1968). In the Karacalar specimen, these characteristics appear to be in line with a more derived animal, as the talonid of $\mathrm{m} 1$ has a narrow, shallow basin and the $\mathrm{m} 2$ is sub-rectangular with a very small paraconid. This fits well with Karacalar being the youngest occurrence of Amphicyon giganteus.

\section{Remarks}

Kuss (1965) erected the genus Megamphicyon for the species giganteus, separating it from Amphicyon on the basis of size and details in the dentition. This generic distinction was not recognised by subsequent authors (e.g., Morales et al. 2003; Peigné et al. 2006b; Morlo et al. 2019a, b), but, recently, Siliceo et al. (2020) reinstated the genus Megamphicyon. As we noted above, the differences in dental morphology between Amphicyon giganteus and A. major are very small. Siliceo et al. (2020), who included well-preserved postcranial elements in their study, state in their introduction that there "are enough morphological differences to support a generic separation". However, in their descriptions and conclusions, they stress the similarity with A. major. As differences seem to be minor, and size is in itself not a very suitable character to distinguish genera, we prefer to keep the traditional classification with both species in Amphicyon, pending a revision of all species of that genus.

Because of the overlap in both geographic and stratigraphic ranges between Amphicyon major and A. giganteus, Siliceo et al. (2020) suggested that the two amphicyonids should have occupied different niches and may even have lived in different ecosystems. Their body mass estimates of $\sim 150 \mathrm{~kg}$ for A. major and $\sim 600 \mathrm{~kg}$ for A. giganteus certainly suggest that the latter was capable of handling larger prey. However, the body mass of A. giganteus may be severely overestimated due to the use of a formula for calculating body mass based on tibial measurements from Figueirido et al. (2011), which is not a very accurate way to estimate body size (Siliceo et al. 2020). Whereas the molar morphology of the two species is very similar, the anterior dentition of A. giganteus is strongly enlarged compared to that of A. major. The exact function of this enlargement, which mostly concerns the incisors, is unknown, but it presumably finds its functionality in the niche differentiation as suggested by Siliceo et al. (2020).

The Karacalar specimen was found in travertine above a layer dated to MN7/8 (Mayda et al. 2013), providing a minimum age for the Amphicyon giganteus occurrence. So far, the youngest finds of the species were all dated to MN6 (La Capetana, La Barranca), making the Karacalar specimen the youngest representative to date. The advanced evolutionary stage of the specimen is in line with it being the youngest find of the species. As a consequence, Amphicyon giganteus appears to have survived longer in Anatolia after it disappeared from Europe, where there is no record after MN6. No A. giganteus material has been found previously in Anatolia, but A. major has been identified in the Çandir and Paşalar localities dated to MN5-MN6 (Mayda et al. 2015). In strata below the Karacalar travertine, a large metapodial of an amphicyonid was found (Mayda et al. 2013), which, given the discovery of the Karacalar skull, may also belong to A. giganteus. A possibility is that A. giganteus being present in Anatolia is part of the greater pattern of migration of Amphicyonidae from Europe into Asia (Peigné et al. 2006a). While a migratory route through southern Europe into Asia has been suggested by Jiangzuo et al. (2019), it was deemed less likely by the authors than a more northwards migratory pattern. While the Asian Amphicyon zhanxiangi bears a resemblance to A. giganteus (Jiangzuo et al. 2019; Sun et al. 2021), the material is from MN5 - MN6 (Sun et al. 2021), older than the material of A. giganteus presented here. Therefore, based on current evidence, it is likely that Anatolia acted as a last refuge for $A$. giganteus. The reason for this southward retreat and the possible replacement of A. major requires further understanding on the ecological differentiation between the two Amphicyon species and the palaeoenvironmental changes in Anatolia at the end of the middle Miocene.

\section{Conclusion}

The specimen found encased in travertine from Karacalar is identified as Amphicyon giganteus, based on its size, doublerooted $\mathrm{p} 2$, robust incisors and canines, $\mathrm{m} 1$ with a narrow talonid basin and metaconid in close proximity to the protoconid, large premolars and small diastemata between them. It represents a more advanced form of A. giganteus, based on the more derived morphology of the $\mathrm{m} 1$ and $\mathrm{m} 2$, in line with the specimen being the youngest representative of the species thus far, based on the age of the deposits directly underlying the travertine. The find suggests that $A$. giganteus found refuge in Anatolia at a time when the species had already disappeared from Europe.

\section{Appendix 1}

See Table 2. 


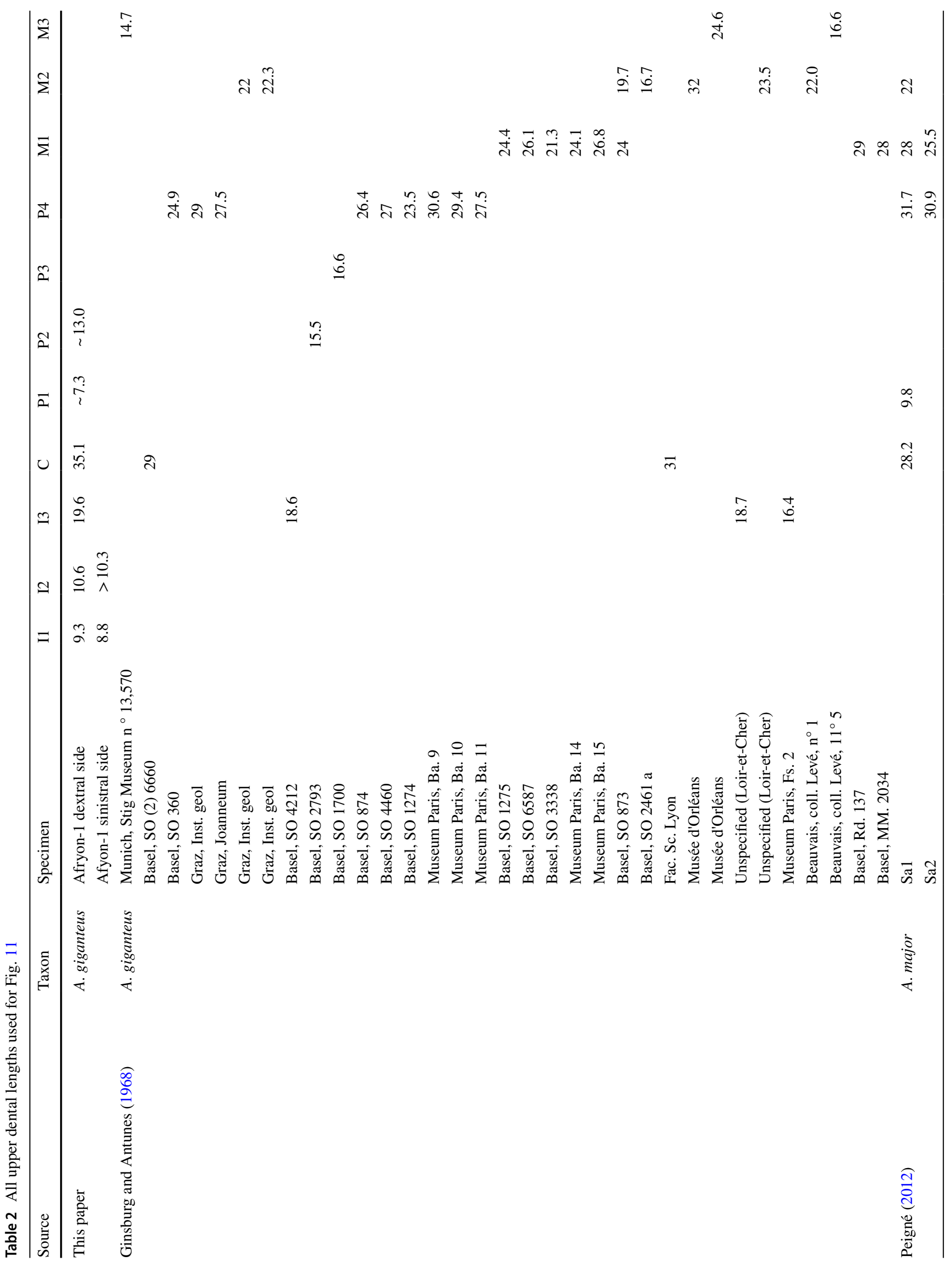




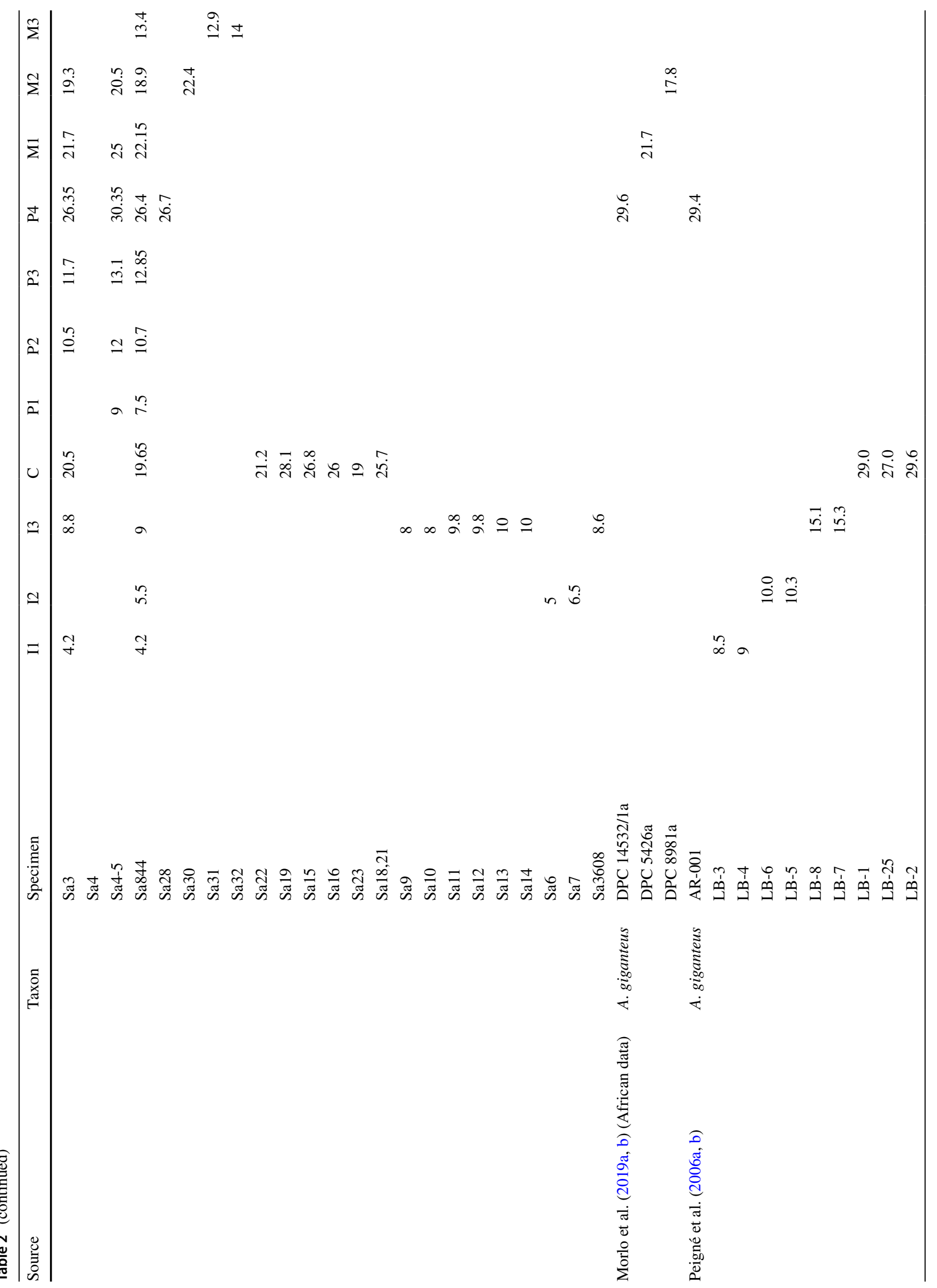




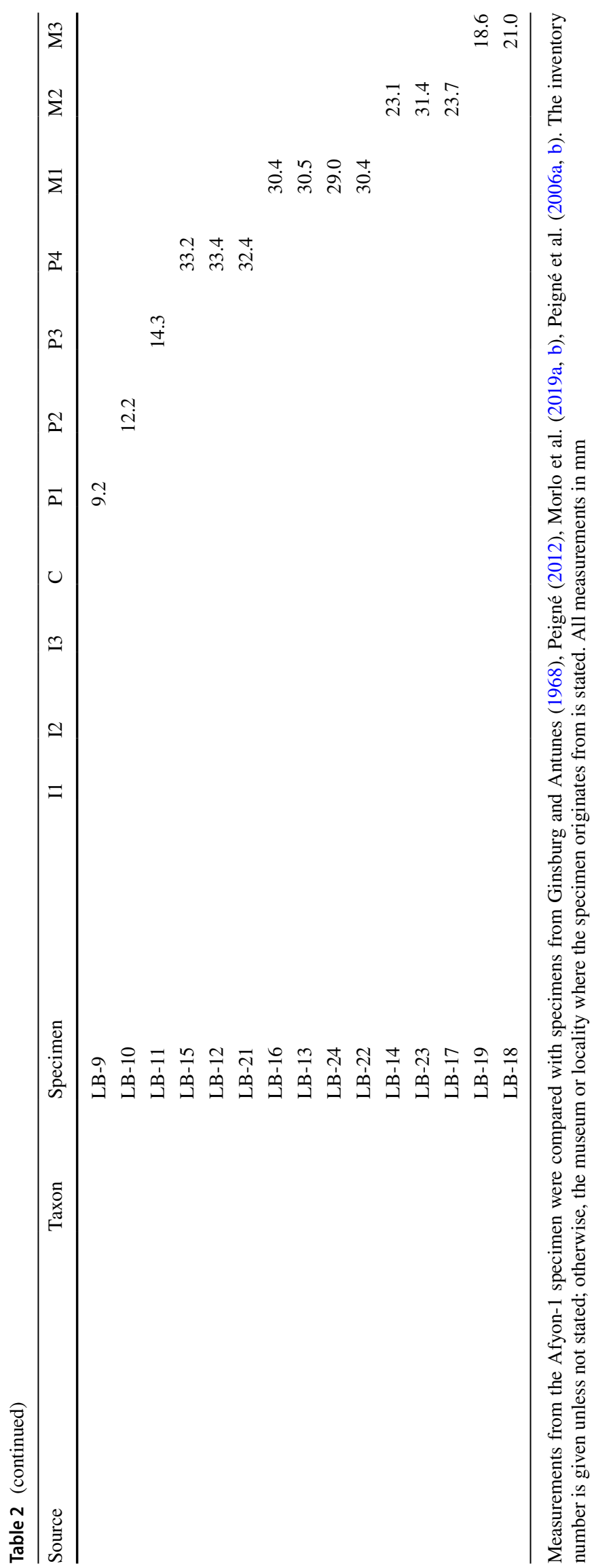

望 Springer 


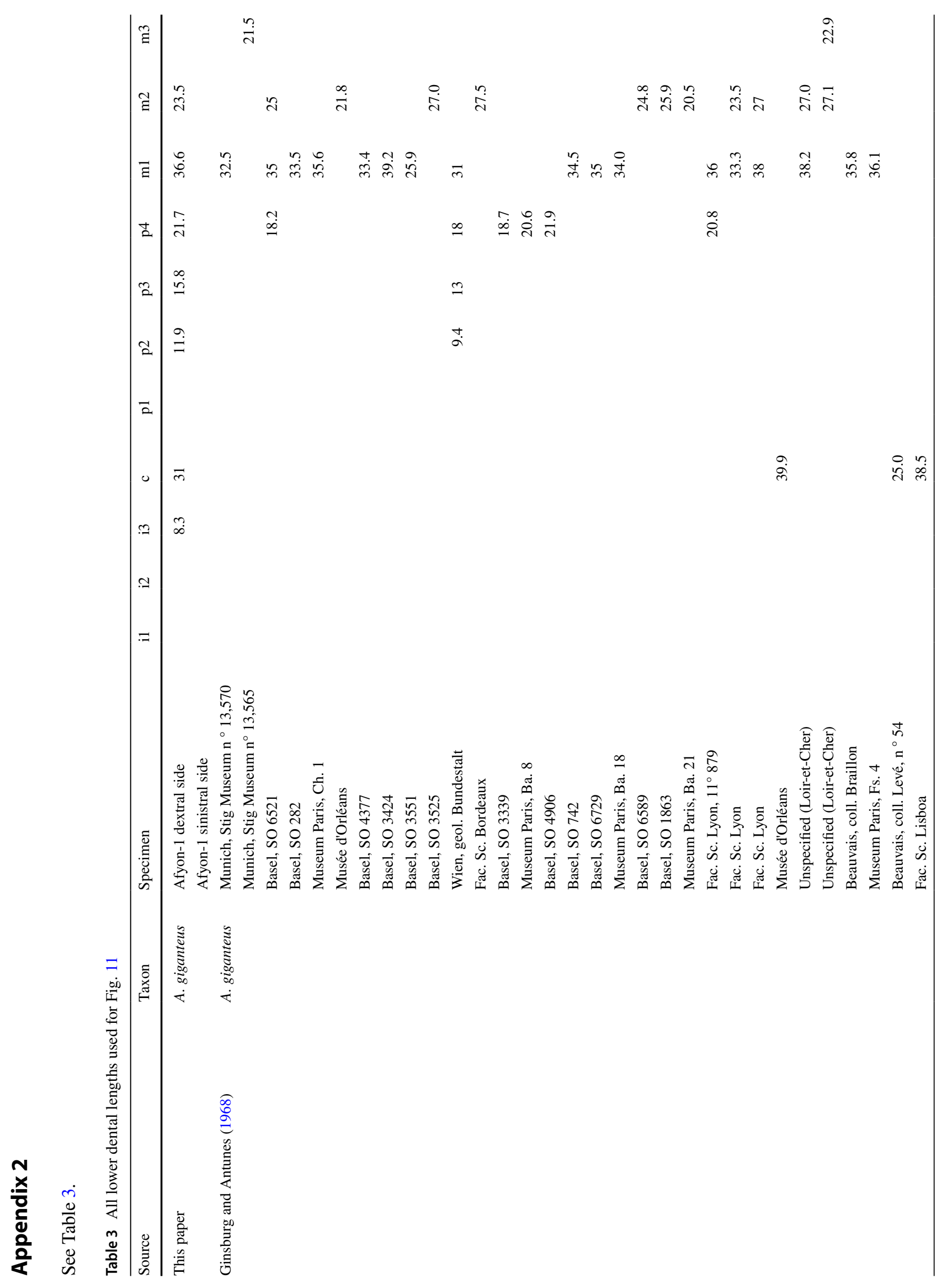




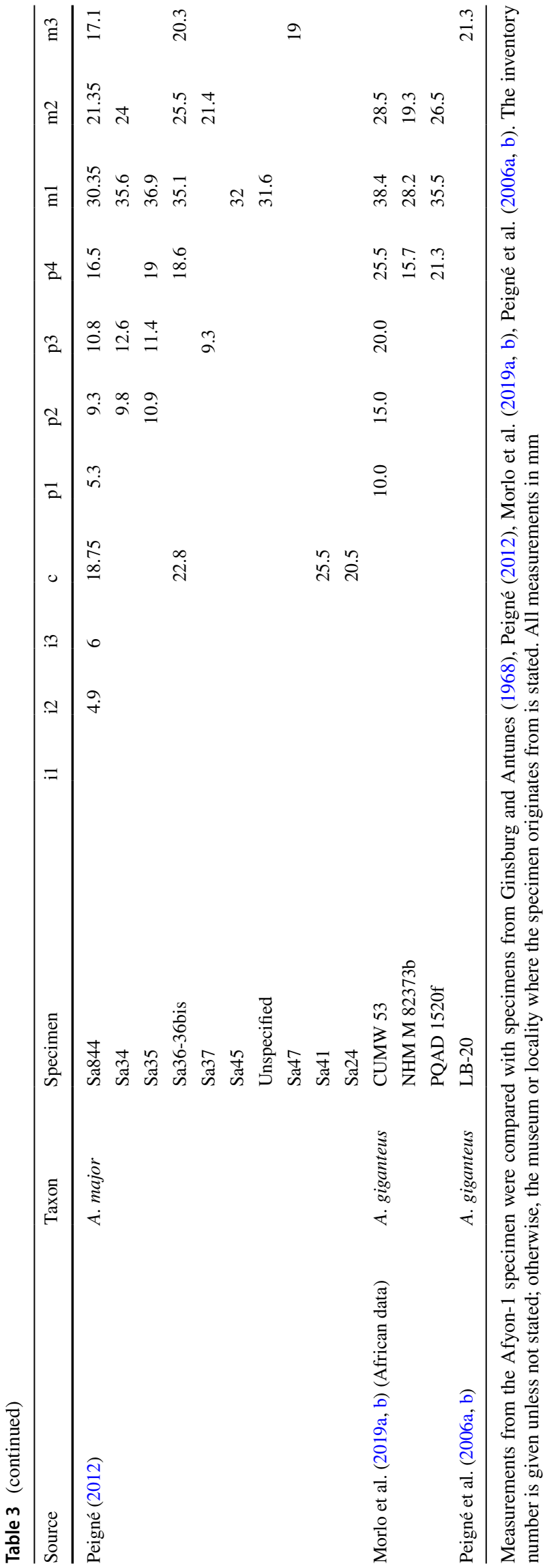

Acknowledgements The authors would like to thank M. Rücklin and A. Sanchez-Erostegui for helping us with getting access to Avizo at home, making this research possible during the COVID-19 pandemic. We would also like to thank M. Rücklin for his help with the programme Avizo. Furthermore, we would like to thank Cèlia Ventura i Gabarró for her help with editing the animation of the 3D reconstruction of the Afyon-1 specimen. Our paper greatly improved with help from the comments of Louis de Bonis, Irina Ruf, Mike Reich and one anonymous reviewer. SM was supported by the Ege University Research Projects TTM/ 001/2015, TTM/001/2016 and 2015 FEN 17.

Funding Open access funding provided by Uppsala University.

Availability of data and materials All data and materials are available through contacting the corresponding author.

Code availability Not applicable.

\section{Declarations}

Conflict of interest The authors of this article have no financial or non-financial interests to declare that are relevant to the content of this article.

Open Access This article is licensed under a Creative Commons Attribution 4.0 International License, which permits use, sharing, adaptation, distribution and reproduction in any medium or format, as long as you give appropriate credit to the original author(s) and the source, provide a link to the Creative Commons licence, and indicate if changes were made. The images or other third party material in this article are included in the article's Creative Commons licence, unless indicated otherwise in a credit line to the material. If material is not included in the article's Creative Commons licence and your intended use is not permitted by statutory regulation or exceeds the permitted use, you will need to obtain permission directly from the copyright holder. To view a copy of this licence, visit http://creativecommons.org/licenses/by/4.0/.

\section{References}

Alan İ., Ş. Şahin, H. Keskin, İ. Altun, B. Bakırhan, V. Balcı, N. Böke, L. Saçlı, Ş. Pehlivan, A. Kop, N. Hanilçi and Ö.F. Çelik. 2007. Orta Toroslar'ın Jeodinamik Evrimi Ereğli (Konya)Ulukışla (Niğde)- Karsantı (Adana)—Namrun (İçel) Yöresi, MTA Raporu No:11006, Ankara.

Bastl, K., D. Nagel, M. Morlo, and U.B. Göhlich. 2018. The Carnivora (Mammalia) from the middle Miocene locality of Gračanica (Bugojno Basin, Gornji Vakuf, Bosnia and Herzegovina). Palaeobiodiversity and Palaeoenvironments 100: 1-13. https://doi.org/10.1007/s12549-0180353-0.

Bergounioux, F.M., and F.C. Crouzel. 1973. Amphicyon major Blainville du Miocène moyen de Sansan (Gers). Annales De Paléontologie (vertébrés) 59: 27-76.

Besang, C., F.J. Eckardt, W. Harre, H. Kreuzer, and P. Müller. 1977. Radiometrische Altersbestimmungen an neogenen Eruptivgesteinen der Türkei. Geologisches Jahrbuch 25: 3-36.

Bowdich, T.E. 1821. An Analysis of the Natural Classifications of Mammalia, For the Use of Students and Travellers. Paris: J. Smith.

Cuvier, G. 1824. Recherches sur les ossemens fossiles ou l'on rétablit les caractères de plusieurs animaux dont les révolutions du globe ont détruit les espèces. Paris: Dufour et d'Ocagne. 
de Beaumont, G. 1984. Des dents d'Amphicyon (Mammifère, Carnivore, Ursidé) du Turolien basal de Kohfidisch, Burgenland, Autriche. Archives Des Sciences 37: 75-83.

de Blainville, H.M.D. 1841. Ostéographie ou Description iconographique comparée du Squelette et du Système dentaire des cinq Classes d'Animaux vertébrés récents et fossiles pour servir de base à la Zoologie et à la Géologie-Mammifères carnassiers: Des Petits-Ours (G. subursus). Paris: J. B Baillière.

Dreimanis, A. 1978. Dating methods of Pleistocene deposits and their problems: I Thermoluminescence Dating. Geoscience Canada 5: 55-60.

Erten, H., S. Sen, and M. Özkul. 2005. Pleistocene mammals from travertine deposits of the Denizli Basin (SW Turkey). Annales De Paléontologie 91: 267-278. https://doi.org/10.1016/j.annpal. 2005.06.001.

Figueirido, B., J.A. Pérez-Claros, R.M. Hunt Jr., and P. Palmqvist. 2011. Body mass estimation in amphicyonid carnivoran mammals: a multiple regression approach from the skull and skeleton. Acta Palaeontologica Polonica 56: 225-246. https://doi. org/10.4202/app.2010.0005.

Ginsburg, L. 1989. Les mammifères des sables du Miocène inférieur des Beilleaux à Savigné-sur-Lathan (Indre-et-Loire). Bulletin Du Muséum National D'histoire Naturelle, Paris 4e Série 11: 101-121.

Ginsburg, L. 1999. Order Carnivora. In The Miocene Land Mammals of Europe, ed. G.E. Rössner and K. Heissig, 109-148. München: F. Pfeil.

Ginsburg, L. 2000. Les espèces du genre Amphicyon et un Amphicyonidé (Mammalia, Carnivora) nouveau des faluns miocènes de l'Anjou. Symbioses 3: 35-40.

Ginsburg, L., and M.T. Antunes. 1968. Amphicyon giganteus, carnassier géant du Miocène. Annales De Paléontologie (vertébrés) 54: $1-32$.

Ginsburg, L., and M.T. Antunes. 1977. Notes sur la géologie et la paléontologie du Miocène de Lisbonne XIX — sur un Amphicyon (Mammalia, Ursidae) du Burdigalien. Comunicações Dos Serviços Geológicos De Portugal 61: 335-342.

Grün, R. 2005. Electron spin resonance dating in paleoanthropology. Evolutionary Anthropology: Issues, News, and Reviews 2: 172-181. https://doi.org/10.1002/evan.1360020504.

Gürbüz, M. 1974. Amphicyon major Blainville discovered in the Middle Miocene beds of Çandir. Bulletin of the Mineral Research and Exploration Institute of Turkey 83: 109-111.

Haeckel, E. 1866. Generelle Morphologie der Organismen-Allgemein Entwicklungsgeschichte der Organismen 2. Berlin: Georg Reimer Verlag.

Hancock, P.L., R.M.L. Chalmers, E. Altunel, and Z. Çakir. 1999. Travitonics: Using travertines in active fault studies. Journal of Structural Geology 21: 903-916.

Jiangzuo, Q., C. Li, S. Wang, and D. Sun. 2019. Amphicyon zhanxiangi, sp. nov., a new amphicyonid (Mammalia, Carnivora) from northern China. Journal of Vertebrate Paleontology 38: 1-12. https://doi.org/10.1080/02724634.2018.1539857.

Kappelman, J., M.C. Alçiçek, N. Kazanci, M. Schultz, M. Özkul, and Ş Şen. 2008. Brief communication: first Homo erectus from Turkey and implications for migrations into temperate Eurasia. American Journal of Physical Anthropology 135: 110-116. https://doi.org/10.1002/ajpa.20739.

Kuss, S. 1965. Revision der europäischen Amphicyoninae (Canidae, Carnivora, Mamm.) ausschliesslich der voroberstampischen Formen. Sitzungsberichte Der Heidelberg Akademie Der Wissenschaften Mathematisch-Naturwissenschaftliche Klasse 1: 1-172.

Lartet, E. 1836. Nomenclature des mammifères et des coquilles qu'il a trouvés dans un terrain d'eau douce près de Simorre et de Sansan (Gers). Bulletin De La Société Géologique De France 7: 217-220.
Lebatard, A.-E., M.C. Alçiçek, P. Rochette, S. Khatib, A. Vialet, N. Boulbes, D.L. Bourlès, F. Demory, G. Guipert, S. Mayda, V.V. Titov, L. Vidal, and H. de Lumley. 2014. Dating the Homo erectus bearing travertine from Kocabaş (Denizli, Turkey) at at least 1.1 Ma. Earth and Planetary Science Letters 390: 8-18. https://doi. org/10.1016/j.eps1.2013.12.031.

Mayda, S., F. Göktaş, A. Tesakov, T. Kaya, V. Titov, and H. Halaçlar. 2013. A new middle Miocene mammalian fauna from AfyonGebeceler (Western Turkey). 66. Turkish Geology Symposium, Ankara/Turkey. 1-5 April 2013, Ankara. Abstract Book: 470-471.

Mayda, S., G.D. Koufos, T. Kaya, and A. Gul. 2015. New carnivore material from the middle Miocene of Turkey. Implications on Biochronology and Palaeoecology. Geobios 48: 9-23. https://doi.org/ 10.1016/j.geobios.2014.11.001.

Mayet, L. 1908. Étude des mammifères miocènes des sables de l'Orléanais et des faluns de la Touraine. Annales De L'université De Lyon, Nouvelle Série I, Science Et Médecine 24: 1-336.

McClusky, S., S. Balassanian, A. Barka, C. Demir, S. Ergintav, I. Georgiev, O. Gurkan, M. Hamburger, K. Hurst, H. Kahle, K. Kastens, G. Kekelidze, R. King, V. Kotzev, O. Lenk, S. Mahmoud, A. Mishin, M. Nadariya, A. Ouzounis, D. Paradissis, Y. Peter, M. Prilepin, R. Reilinger, I. Sanli, H. Seeger, A. Tealeb, M.N. Toksöz, and G. Veis. 2000. Global Positioning System constraints on plate kinematics and dynamics in the eastern Mediterranean and Caucasus. Journal of Geophysical Research: Solid Earth 105: 5695-5719. https://doi.org/10.1029/1999jb900351.

McClusky, S., R. Reilinger, S. Mahmoud, D. Ben Sari, and A. Tealeb. 2003. GPS constraints on Africa (Nubia) and Arabia plate motions. Geophysical Journal International 155: 126-138. https://doi.org/10.1046/j.1365-246X.2003.02023.x.

Metin, S., S de Genç, and V. Bulut. 1987. Afyon ve dolayının jeolojisi. MTA Jeoloji Etüdleri Dai. 2113: 74.

Morales, J., M. Pickford, D. Soria, and S. Fraile. 1998. New carnivores from the basal middle Miocene of Arrisdrift, Namibia. Eclogae Geologicae Helvetiae 91: 27-40.

Morales, J., M. Pickford, S. Fraile, M.J. Salesa, and D. Soria. 2003. Creodonta and carnivora from Arrisdrift, early middle Miocene of southern Namibia. Memoir of the Geological Survey of Namibia 19 (19): 177-194.

Morlo, M., E.R. Miller, K. Bastl, M.K. Abdelgawad, M. Hamdan, A.N. El-Barkooky, and D. Nagel. 2019a. New Amphicyonids (Mammalia, Carnivora) from Moghra, early Miocene Egypt. Geodiversitas 41: 731-745. https://doi.org/10.5252/geodiversitas2019v41a21.

Morlo, M., K. Bastl, J. Habersetzer, T. Engel, B. Lischewsky, H. Lutz, and D. Nagel. 2019b. The apex of amphicyonid hypercarnivory: solving the riddle of Agnotherium antiquum Kaup, 1833 (Mammalia, Carnivora). Journal of Vertebrate Paleontology. https://doi. org/10.1080/02724634.2019.1705848.

Özgül, N. 1976. Toroslar'm bazı temel jeoloji özellikleri. Bulletin of the Geological Society of Turkey 19: 65-78.

Peigné, S. 2012. Carnivora de Sansan. In Mammifères de Sansan, Mémoires du Muséum national d'Histoire naturelle 203, ed. S. Peigné and S. Sen, 559-660. Paris: Publications Scientifiques du Muséum.

Peigné, S., and E. Heizmann. 2003. The Amphicyonidae (Mammalia: Carnivora) from Ulm-Westtangente (MN 2, Early Miocene), Baden-Württemberg, Germany-Systematics and ecomorphology. Stuttgarter Beiträge Zur Naturkunde Serie B (geologie Und Paläontologie) 343: 1-133.

Peigné, S., Y. Chaimanee, C. Yamee, P. Tian, and J.J. Jaeger. 2006a. A new amphicyonid (Mammalia, Carnivora, Amphicyonidae) from the late middle Miocene of northern Thailand and a review of the amphicyonine record in Asia. Journal of Asian Earth Sciences 26 (5): 519-532. https://doi.org/10.1016/j.jseaes.2004.11.003. 
Peigné, S., M.J. Salesa, M. Antón, and J. Morales. 2006b. New data on carnivores from the Middle Miocene (Upper Aragonian, MN 6) of Arroyo del Val area (Villafeliche, Zaragoza Province, Spain). Estudios Geológicos 62: 359-374. https://doi.org/10.3989/egeol. 0662131.

Peigné, S., M.J. Salesa, M. Antón, and J. Morales. 2008. A new amphicyonine (Carnivora: Amphicyonidae) from the upper Miocene of batallones-1 Madrid, Spain. Palaeontology 51: 943-965. https:// doi.org/10.1111/j.1475-4983.2008.00788.x.

Pentecost, A. 2005. Travertine. Berlin: Springer.

Reilinger, R., and S. McClusky. 2011. Nubia-Arabia-Eurasia plate motions and the dynamics of Mediterranean and Middle East tectonics. Geophysical Journal International 186: 971-979. https:// doi.org/10.1111/j.1365-246X.2011.05133.x.

Saraç, G. 2003. Türkiye Omurgalı Fosil Yataklart. Scientific Report No. 10609. Ankara: General Directorate of the Mineral Research and Exploration of Turkey (MTA).

Schinz, R.H. 1825. Das Thierreich, eingetheilt nach dem Bau der Thiers als Grundlage ihrer Naturgeschichte und der vergleichenden Anatomie vond den Herrn Ritter von Cuvier, Vierter
Band, Zoophyten. Stuttgart and Tübingen: J.G. Cotta'schen Buchhandlung. https://doi.org/10.5962/bhl.title.120160.

Schmidt-kittler, N.T. 1976. Carnivores from the Neogene of Asia Minor. Palaeontographica Abteilung A 155: 1-131.

Siliceo, G., J. Morales, M. Antón, and M.J. Salesa. 2020. New fossils of Amphicyonidae (Carnivora) from the middle Miocene (MN6) site of Carpetana (Madrid, Spain). Geodiversitas 42: 223-238. https://doi.org/10.5252/geodiversitas2020v42a15.

Sun, Z., A. Han, Y. Li, Q. Jiangzuo, S. Wang, and S. Li. 2021. New material of Amphicyon zhanxiangi from laogou, linxia basin suggests a possible southern dispersal with increasing omnivory. Historical Biology. https://doi.org/10.1080/08912963.2021.1949009.

ThermoFisher Scientific. 2018. 3.5 Segmentation of 3D images, p. 96-99. Thermo Scientific Avizo Software 9 User's Guide.

Viranta, S. 1996. European Miocene Amphicyonidae-taxonomy, systematics and ecology. Acta Zoologica Fennica 204: 1-61.

Viret, J. 1929. Tomocyon grivensis n. gen. n. sp. et les canidés de La Grive Saint-Alban. Bulletin De La Société Géologique De France 29: 217-226.

Walker, M.J.C. 2005. Quaternary Dating Methods. Chichester: Wiley. 